\title{
Management of locally recurrent nasopharyngeal carcinoma
}

\author{
Leea, Anne W. M.
}

2019-09

Leea , A W M , Ng , W T , Chan , J Y W , Corry , J, Mäkitie , A, Mendenhall , W M , Rinaldo , A , Rodrigo , J P , Saba , N F , Strojan , P , Suarez , C, Vermorken , J B , Yom , S S \& Ferlito, A 2019 , ' Management of locally recurrent nasopharyngeal carcinoma ', Cancer Treatment Reviews , vol. 79 , 101890 . https://doi.org/10.1016/j.ctrv.2019.101890

http://hdl.handle.net/10138/320963

https://doi.org/10.1016/j.ctrv.2019.101890

publishedVersion

Downloaded from Helda, University of Helsinki institutional repository.

This is an electronic reprint of the original article.

This reprint may differ from the original in pagination and typographic detail.

Please cite the original version. 
Tumour Review

\title{
Management of locally recurrent nasopharyngeal carcinoma ${ }^{\text {th }}$
}

\author{
Anne W.M. Lee ${ }^{\mathrm{a}, \mathrm{b}}$, Wai Tong Ng ${ }^{\mathrm{c}, *}$, Jimmy Y.W. Chan ${ }^{\mathrm{d}}$, June Corry ${ }^{\mathrm{e}}$, Antti Mäkitie ${ }^{\mathrm{f}, \mathrm{g}, \mathrm{h}}$, \\ William M. Mendenhall ${ }^{\mathrm{i}}$, Alessandra Rinaldo ${ }^{\mathrm{j}}$, Juan P. Rodrigo ${ }^{\mathrm{k}, 1}$, Nabil F. Saba ${ }^{\mathrm{m}}$, \\ Primož Strojan $^{\mathrm{n}}$, Carlos Suárez ${ }^{\mathrm{o}, \mathrm{p}}$, Jan B. Vermorken ${ }^{\mathrm{q}}$, Sue S. Yom ${ }^{\mathrm{r}}$, Alfio Ferlito \\ ${ }^{a}$ Department of Clinical Oncology, Li Ka Shing Faculty of Medicine, The University of Hong Kong, Hong Kong \\ ${ }^{\mathrm{b}}$ Clinical Oncology Center, The University of Hong Kong-Shenzhen Hospital, Shenzhen, People's Republic of China \\ ${ }^{\mathrm{c}}$ Department of Clinical Oncology, Pamela Youde Nethersole Eastern Hospital, Hong Kong \\ ${ }^{\mathrm{d}}$ Department of Surgery, Li Ka Shing Faculty of Medicine, The University of Hong Kong, Hong Kong \\ e Department Radiation Oncology, GenesisCare St Vincent's Hospital, Melbourne, Australia \\ ${ }^{\mathrm{f}}$ Department of Otorhinolaryngology - Head and Neck Surgery, HUS Helsinki University Hospital and University of Helsinki, Helsinki, Finland \\ ${ }^{\mathrm{g}}$ Research Program in Systems Oncology, Faculty of Medicine, University of Helsinki, Finland \\ ${ }^{\mathrm{h}}$ Division of Ear, Nose and Throat Diseases, Department of Clinical Sciences, Intervention and Technology, Karolinska Institutet and Karolinska University Hospital, \\ Stockholm, Sweden \\ ${ }^{\mathrm{i}}$ Department of Radiation Oncology, University of Florida College of Medicine, Gainesville, FL, United States \\ ${ }^{\mathrm{j}}$ University of Udine School of Medicine, Udine, Italy \\ ${ }^{\mathrm{k}}$ Instituto Universitario de Oncología del Principado de Asturias, University of Oviedo, Oviedo, Spain \\ ${ }^{1}$ Department of Otolaryngology, Hospital Universitario Central de Asturias, Oviedo, Spain \\ ${ }^{\mathrm{m}}$ Department of Hematology and Medical Oncology, Winship Cancer Institute, Emory University School of Medicine, Atlanta, Georgia \\ ${ }^{\mathrm{n}}$ Department of Radiation Oncology, Institute of Oncology, Ljubljana, Slovenia \\ ${ }^{\circ}$ Instituto de Investigación Sanitaria del Principado de Asturias and CIBERONC, ISCIII, Oviedo, Spain \\ ${ }^{\mathrm{P}}$ Instituto Universitario de Oncología del Principado de Asturias, University of Oviedo, Oviedo, Spain \\ ${ }^{\mathrm{q}}$ Department of Medical Oncology, Antwerp University Hospital, Belgium \\ ${ }^{\mathrm{r}}$ Department of Radiation Oncology, University of California, San Francisco, United States \\ ${ }^{\mathrm{s}}$ Coordinator of the International Head and Neck Scientific Group, Padua, Italy
}

\section{A R T I C L E I N F O}

\section{Keywords:}

Nasopharyngeal carcinoma

Recurrent

Nasopharyngectomy

Radiotherapy

Prognostic factor

\begin{abstract}
A B S T R A C T
As a consequence of the current excellent loco-regional control rates attained using the generally accepted treatment paradigms involving intensity-modulated radiotherapy for nasopharyngeal carcinoma (NPC), only $10-20 \%$ of patients will suffer from local and/or nodal recurrence after primary treatment. Early detection of recurrence is important as localized recurrent disease is still potentially salvageable, but this treatment often incurs a high risk of major toxicities. Due to the possibility of radio-resistance of tumors which persist or recur despite adequate prior irradiation and the limited tolerance of adjacent normal tissues to sustain further additional treatment, the management of local failures remains one of the greatest challenges in this disease. Both surgical approaches for radical resection and specialized re-irradiation modalities have been explored. Unfortunately, available data are based on retrospective studies, and the majority of them are based on a small number of patients or relatively short follow-up. In this article, we will review the different salvage treatment options and associated prognostic factors for each of them. We will also propose a treatment algorithm based on the latest available evidence and discuss the future directions of treatment for locally recurrent NPC.
\end{abstract}

\section{Introduction}

The previous review by the International Head and Neck Scientific Group (IHNSG) on recurrent nasopharyngeal carcinoma (NPC) summarized the available data that had emerged over the past decade prior to 2010 to identify the scope of the problem [1]. With the adoption of intensity-modulated radiotherapy (IMRT) \pm stereotactic radiotherapy (SRT) for the primary management of NPC in the contemporary era, a renewed review of strategies is needed for the management of recurrent NPC as most failures are now likely to be related to radioresistance.

\footnotetext{
This paper was written by members and invitees of the International Head and Neck Scientific Group (www.IHNSG.com).

* Corresponding author at: Department of Clinical Oncology, Pamela Youde Nethersole Eastern Hospital, 3 Lok Man Road, Chai Wan, Hong Kong.

E-mail address: ngwt1@ha.org.hk (W.T. Ng).
} 
Furthermore, most of the adjacent normal tissues have already endured varying degrees of damage from the previous course of high-dose radiotherapy (RT). This poses additional complexity and challenges in the salvage treatment. In this article, we will focus on the different salvage options reported in the recent decade and their associated prognostic factors. A treatment algorithm based on the latest evidence is proposed and we will also explore the various ways of the future direction of various approaches that might be useful in tackling this challenging condition.

\section{Scope of the problem}

Using IMRT in the primary setting, excellent loco-regional control rates have been consistently achieved in the treatment of NPC $[2,3]$. A study by the Hong Kong Nasopharyngeal Cancer Study Group (HKNPCSG-1301 study) recently reported eight-year survival outcomes for NPC patients receiving primary treatment by IMRT with/without chemotherapy at public oncology centers in Hong Kong [4]. Amongst the 3328 patients included, $14 \%$ of them developed local recurrence or persistent disease, while $21 \%$ had concomitant distant metastasis at the time of local relapse. The median time from the diagnosis of primary NPC to local recurrence was approximately 30 months. Among the patients with recurrence, $41 \%$ had local recurrence detected within the first two years, $44 \%$ in the second to fifth year and $15 \%$ of the recurrences were detected more than five years later.

The majority of the local recurrences were noted to be in the high dose zone $[5,6]$; while marginal failure $(\leq 2.1 \%)$ and geographical miss $(0-1 \%)$ were uncommon. Hence, it is obvious that most of the recurrences result from radio-resistance [7]. In addition, these radiation resistant tumors are surrounded by critical organs at risk (OAR) that have already absorbed near tolerance radiation dose.

\section{Detection of local recurrence}

Vigilant follow-up by physical and endoscopic examination, surveillance monitoring by magnetic resonance imaging (MRI) and determination of plasma Epstein-Barr virus deoxyribonucleic acid (EBV DNA) level at regular intervals are recommended for all NPC patients following primary treatment. As subsequently illustrated in this manuscript, the importance of early detection cannot be over-emphasized as this is associated not only with a higher chance of survival, but also with better salvage options with lower toxicities.

\section{Endoscopy}

Periodic endoscopic examination is the one of the main modalities for follow-up assessment [8]. The emerging development of narrowband imaging endoscopy offers a diagnostic advantage. Wang et al. reported that narrow-band imaging endoscopy could enhance the detection rate of mucosal recurrent lesions $(88 \%$ for both sensitivity and specificity) [9], and also noted that post-radiation effects may give rise to false-positive results. However, neither method could detect deep seated or skull base recurrence.

\section{MRI}

MRI is another main modality for follow-up assessment, but interpretation still remains challenging [10]. Both recurrent tumor and posttherapeutic inflammatory changes may display hyperintensity with intense enhancement on T2-weighted (T2W) images on conventional MRI, leading to equivocal distinction between the two differential diagnoses [11]. Similarly, post-RT induced scar tissue and bony changes also pose diagnostic difficulty in differentiating from the highly variable appearance of recurrent tumors [12]. Diffusion-weighted imaging is now increasingly used as distinction can be improved by the differences in intravoxel incoherent motion-diffusion and perfusion morphology patterns $[13,14]$.

\section{Positron emission tomography-computed tomography (PET-CT)}

PET-CT at the time of local recurrence is valuable as up to $\sim 20 \%$ of patients have been reported to have concomitant distant metastasis at the time of local recurrence $[15,16]$. Furthermore, Yen et al. reported that FDG-PET was superior to MRI in detecting residual/recurrent NPC, showing improvement in sensitivity (100\% vs. $62 \%)$, specificity $(93 \%$ vs. $44 \%$ ) and accuracy (96\% vs. $49 \%$ ) [17].

Another recent meta-analysis revealed that both PET-CT and singlephoton emission computed tomography (SPECT) facilitated accurate detection of residual/locally recurrent NPC. Superiority to MRI in the distinction between recurrent disease versus post-RT changes was demonstrated: the pooled specificity estimates for PET-CT (93\%) and SPECT (81\%) were higher than for MRI (76\%) [18]. However, it should be noted that PET-CT may give false-positive results arising from postRT mucosal inflammatory changes/mucositis or osteonecrosis.

\section{EBV DNA}

Despite the lack of prospective data and the need of standardization of the test, monitoring of plasma EBV DNA is found to be useful for follow-up assessment, especially for the detection of distant failures $[19,20]$. However, its sensitivity in the detection of local recurrences is relatively low. Elevated plasma EBV DNA level was seen in 55\% to $96 \%$ of patients with distant metastases, but varied from $0 \%$ to $67 \%$ in patients with local and/or nodal recurrence [20-24]. Nonetheless, plasma EBV DNA level is still useful, as a high pre-operative level may identify those at a higher risk of distant failure after attempt at salvage surgery [25].

The use of trans-oral nasopharyngeal brush biopsy for EBV DNA in the detection of local NPC recurrence has also been reported [26]. In a series by Hao et al., nasopharyngeal swab testing for PCR-based latent membrane protein (LMP)-1 gene and Epstein-Barr nuclear antigen (EBNA)-1 gene was used to monitor local recurrence in 84 NPC patients [27]. Of the 12 patients who were tested positive for both LMP1 and EBNA1, 11 developed local recurrence (sensitivity 91.7\%, specificity 98.6\%). This method is convenient and simple but its reliability for detecting deep-seated lesions may be limited.

\section{Surgical approach}

There is as yet no randomized controlled trial offering a head to head comparison of surgery versus re-irradiation or systemic therapy in the management of recurrent NPC. Retrospective comparisons are hindered by various confounding factors: eligible surgical candidates usually exhibit more clinically favorable profiles with lower disease volume, earlier r-T category, better performance status and fewer medical co-morbidities.

Retrospective studies have suggested that the local salvage rates were similar between surgery and re-irradiation [28], but a recent casematched study by You et al. demonstrated that endoscopic nasopharyngectomy offered more optimal treatment outcomes, better quality of life (QOL) and a significantly lower rate of treatment-related complications as compared with salvage IMRT [29].

In view of the high incidence of severe late toxicities associated with re-irradiation [30], surgical salvage should be considered in resectable cases. Various surgical techniques (including endoscopic resection \pm robotic assistance [31] and open nasopharyngectomy via various approaches [32]) could be adopted depending on the disease extent and location.

The resectability of the recurrent diseases can be broadly categorized as follows:

- Easily resectable: rT1 disease, rT2-3 with limited parapharyngeal space involvement or disease confined to the base of sphenoid sinus.

- Potentially resectable (definition could vary depending on availability of expertise) [33]: involvement of the internal carotid artery (ICA), limited invasion to the clivus, posterior maxillary sinus, 
Table 1

Comparison between open surgery and endoscopic resection.

\begin{tabular}{|c|c|c|}
\hline & Open surgery & Endoscopic resection \\
\hline \multirow[t]{3}{*}{ Advantages } & Better macroscopic exposure to the operating field & Less invasive \\
\hline & Most suitable for more locally advanced tumors close to internal & Avoids the morbidities inherent with open procedure \\
\hline & carotid artery & $\begin{array}{l}\text { Most suitable for centrally located tumors, especially rT1-T2 with limited } \\
\text { parapharyngeal involvement }\end{array}$ \\
\hline Procedure-specific complications & $\begin{array}{l}\text { Cosmesis, facial numbness, trismus, palatal fistula formation, } \\
\text { nasal blockage, ectropion, epiphora }\end{array}$ & Flap necrosis with flap coverage of the NP defect \\
\hline Other complications in common & \multicolumn{2}{|c|}{$\begin{array}{l}\text { Skull base osteonecrosis, inadvertent damage to the carotid vessel, velopharyngeal insufficiency, eustachian tube dysfunction causing otitis media } \\
\text { with effusion }\end{array}$} \\
\hline
\end{tabular}

pterygoid process and petrous apex.

- Unresectable: tumor invading both cortexes of the clivus (difficult to repair the dura in a water-tight manner if inadvertently damaged), significant involvement of the lateral wall of the sphenoid sinus (due to the presence of internal carotid artery, optic nerve and abducens nerve), frank cavernous sinus or intracranial invasion, and multiple areas of skull base involvement [33].

The advantages and disadvantages of open surgery vs. endoscopic resection for early resectable recurrences are delineated in the Table 1. Irrespective of the operative approach, exposed ICA, bone and dura should be covered by a muscle flap. One approach is to use the vastus lateralis muscle free flap tunneled medial to the body of the mandible to the neck, where a microvascular anastomosis will be carried out [34].

Special surgical techniques are also needed for recurrent disease with carotid artery involvement. A two-stage operation has been described: an extra-to-intracranial vascular bypass using the autologous radial artery or long saphenous vein is performed during the first-stage. After ascertaining the patency of the bypass by CT angiogram, the tumor including the involved bone and ICA will be removed en-bloc in the second operation [35].

The treatment outcomes of open surgery and endoscopic resection are summarized in Table 2 [36-46]. Irrespective of treatment methods, local control exceeding $50 \%$ has been consistently reported in modern series. Peri-operative mortality rate seems low and late complications appear to be significantly less common than after re-irradiation, particularly if an endoscopic approach has been used. Furthermore, global quality of life (QOL) after salvage nasopharyngectomy has been reported as generally good; only palatal fistula and osteoradionecrosis might potentially affect the social life of the patients [47]. The results of removal of recurrent nasopharyngeal carcinomas after radiotherapy failure are encouraging for rT1-T2 and select T3 tumors, and even for
T4 tumors with extracranial extension. On the other hand, patients with rT4 tumors with intracranial involvement generally recur locally or die due to development of metastatic disease. Although some authors report encouraging results in the case of intracavernous involvement, surgical salvage of NPC recurrence with significant intracranial extension is usually not justified.

While the role of surgical treatment is increasingly recognized if expertise is available, the role of adjunctive RT and/or chemotherapy remains unclear, except that most would agree to consider post-operative RT for patients with positive resection margins [48].

\section{Re-irradiation approach}

Various studies conducted in recent years have advocated IMRT, SRT or intensity-modulated proton therapy (IMPT) for re-irradiation. These techniques have surpassed the roles of brachytherapy, 3D-conformal RT and other older techniques [1]. Various radiobiological factors including total dose, dose/fraction, altered fractionation, dose tolerance of OAR (especially the nasopharyngeal mucosa, carotid vessels and neurological structures) and their prior dose exposure should be carefully considered. Furthermore, the best quality control of RT technique and precision set-up should be adopted for maximal sparing of the neighboring uninvolved normal tissues.

IMRT is universally the most used modality at present, and most protocols aim to deliver a radiation dose of $\geq 60 \mathrm{~Gy}$ to the recurrent gross tumor volume (rGTV), to achieve a promising local control rate of $52-86 \%$ [49-55]. Table 3 summarizes the recent studies based on IMRT $[7,16,49-51,53-61]$ and provides an in-depth analysis of the effect of re-irradiation on overall survival. Such studies can be broadly divided into two groups based on the reirradiation dose ( $\leq 60 \mathrm{~Gy}$ vs. $>60 \mathrm{~Gy}$ ). The reported five-year survival rates range from 28 to $60 \%$, with rT3-T4 disease at the lower end of the survival spectrum. Fatal

Table 2

Efficacy and major complications of selected series of nasopharyngectomy for recurrent nasopharyngeal carcinoma.

\begin{tabular}{|c|c|c|c|c|c|c|c|}
\hline \multirow[t]{2}{*}{ Author } & \multirow[t]{2}{*}{ No. } & \multirow[t]{2}{*}{ rT1 (\%) } & \multirow[t]{2}{*}{ Post-operative RT (\%) } & \multicolumn{2}{|c|}{ Salvage rate ( 5 year) } & \multicolumn{2}{|l|}{ Severe complications } \\
\hline & & & & LC (\%) & OS (\%) & Carotid injury/Massive bleeding (acute or late) (\%) & Hospital mortality (\%) \\
\hline \multicolumn{8}{|l|}{ Open surgery } \\
\hline King et al. [36] & 31 & 65 & 77 & 43 & 47 & 3 & 0 \\
\hline Fee et al. [37] & 37 & 59 & 22 & 67 & 60 & 3 & 3 \\
\hline Hao et al. [38] & 53 & 51 & 39 & 54 & 49 & 4 & 0 \\
\hline Vlantis et al. [39] & 97 & 55 & 73 & 47 & 52 & 3 & 0 \\
\hline Wei et al. [40] & 246 & NS & NS & 74 & 56 & 1 & 0 \\
\hline Bian et al. [41] & 71 & 38 & NS & 54 & 42 & 0 & 0 \\
\hline $\mathrm{Ng}$ et al. [42] & 20 & 90 & NS & 70 & 67 & 0 & 0 \\
\hline \multicolumn{8}{|l|}{ Endoscopic surgery } \\
\hline Chen et al. [43] & 37 & 46 & 0 & $86^{*}$ & $84^{*}$ & 0 & 0 \\
\hline \multirow[t]{2}{*}{ Ko et al. [44] } & 28 & 43 & 7 & $\mathrm{~T} 1-100 *$ & $59 *$ & 4 & 0 \\
\hline & & & & $\mathrm{T} 2-42^{*}$ & & & \\
\hline Zou et al. [45] & 92 & 50 & NS & NS & 78 & NS & NS \\
\hline Liu et al. [46] & 91 & 33 & NS & NS & 38 & 10 & 0 \\
\hline
\end{tabular}

Abbreviation: LC - local control, NS - not stated, OS - overall survival.

* 2 year outcomes. 
Table 3

Cross-study comparisons for selected series of recurrent nasopharyngeal carcinoma treated with intensity modulated radiotherapy.

\begin{tabular}{|c|c|c|c|c|c|c|c|c|c|}
\hline Author & $\begin{array}{l}\text { No. of } \\
\text { patients }\end{array}$ & $\%$ rT3-4 & Dose (Gy) & $\begin{array}{l}\text { Median } \\
\text { FU } \\
\text { (months) }\end{array}$ & $\begin{array}{l}\text { Endpoint } \\
\text { (year) }\end{array}$ & $\begin{array}{l}\text { Local control } \\
(\%)\end{array}$ & $\begin{array}{l}\text { OS } \\
(\%)\end{array}$ & $\begin{array}{l}\text { Severe complications } \\
(\%)\end{array}$ & Fatal complication (\%) \\
\hline \multicolumn{10}{|c|}{ Planned total radiation dose $>60 \mathrm{~Gy}$} \\
\hline Qiu et al. [51] & 70 & 57 & $\begin{array}{l}\text { 50-77.4 } \\
\text { (median 70) }\end{array}$ & 25 & 3 & $\begin{array}{l}49 \\
\text { (LRRFS) }\end{array}$ & 52 & $\begin{array}{l}\text { mucosal necrosis - } 16 \\
\text { CN palsy - } 24 \\
\text { TLN - NR } \\
\text { massive epistaxis - } 9\end{array}$ & massive epistaxis - 9 \\
\hline Han et al. [49] & 239 & 75 & $\begin{array}{l}\text { 61.7-78.7 } \\
\text { (mean 69.9) }\end{array}$ & 29 & 5 & $\begin{array}{l}86 \\
\text { (LRFS) }\end{array}$ & 45 & $\begin{array}{l}\text { mucosal necrosis - } 41 \\
\text { brain injury }-29\end{array}$ & overall - 35 \\
\hline Chen et al. [54] & 54 & 80 & $\begin{array}{l}49.8-76.6 \\
\text { (mean } 70 \text { ) }\end{array}$ & 17 & 2 & $\begin{array}{l}64 \\
\text { (LPFS) }\end{array}$ & 44 & $\begin{array}{l}\text { mucosal necrosis }-32 \\
\text { dysphagia }-20 \\
\text { TLN - } 19 \\
\text { massive epistaxis - } 11\end{array}$ & overall - 25 \\
\hline Hua et al. [50] & 151 & 81 & $\begin{array}{l}62.1-77.6 \\
\text { (mean 70.4) }\end{array}$ & 40 & 3 & $\begin{array}{l}83 \\
(\mathrm{LCR})\end{array}$ & 46 & $\begin{array}{l}\text { mucosal necrosis }-20 \\
\mathrm{CN} \text { palsy }-13 \\
\text { brain injury }-22\end{array}$ & $\begin{array}{l}\text { massive epistaxis - } 19 \\
\text { brain injury - } 17\end{array}$ \\
\hline Tian et al. [55] & 117 & 79 & $65.4-73.1$ & 25 & 3 & $\begin{array}{l}64-71^{\mathrm{b}} \\
\text { (LFFS) }\end{array}$ & 48 & $\begin{array}{l}\text { mucosal necrosis }-39 \\
\text { CN palsy }-13 \\
\text { TLN - } 21\end{array}$ & $\begin{array}{l}\text { overall - } 32 \text { including } \\
\text { mucosal necrosis / bleeding - } \\
20 \\
\text { TLN }-4\end{array}$ \\
\hline Tian et al. [56] & 245 & 100 & $\begin{array}{l}60.1-78.7 \\
\text { (median 70) }\end{array}$ & 24 & 5 & $\begin{array}{l}61 \\
\text { (LRFFS) }\end{array}$ & 28 & $\begin{array}{l}\text { mucosal necrosis }-27 \\
\text { CN palsy }-14 \\
\text { TLN }-22 \\
\text { massive epistaxis }-16\end{array}$ & $\begin{array}{l}\text { overall - } 29 \text { including } \\
\text { mucosal necrosis / bleeding - } \\
13 \\
\text { TLN }-7\end{array}$ \\
\hline Kong et al. [7] & 77 & 39 & $\begin{array}{l}46.2-70 \\
\text { (median 66) }\end{array}$ & 26 & 3 & $\begin{array}{l}67 \\
\text { (LPFS) }\end{array}$ & 52 & $\begin{array}{l}\text { mucosal necrosis }-40 \\
\text { CN palsy }-26 \\
\text { TLN - } 9\end{array}$ & $\begin{array}{l}\text { overall - } 53 \text { including } \\
\text { mucosal necrosis / bleeding - } \\
22\end{array}$ \\
\hline Kong et al. [57] & 184 & 65 & $\begin{array}{l}42-77 \\
\text { (median 66.7) }\end{array}$ & 33 & 3 & $\begin{array}{l}85 \\
\text { (LRFS) }\end{array}$ & 46 & $\begin{array}{l}\text { mucosal necrosis }-30 \\
\mathrm{CN} \text { palsy }-11\end{array}$ & mucosal necrosis - 24 \\
\hline \multicolumn{10}{|c|}{ Planned total radiation dose $\leq 60 \mathrm{~Gy}$} \\
\hline Chua et al. [53] & 31 & 75 & $\begin{array}{l}50-60^{\mathrm{a}} \\
\text { (median 54) }\end{array}$ & 11 & 1 & $\begin{array}{l}65 \\
\text { (LPFS) }\end{array}$ & 63 & $\begin{array}{l}\mathrm{CN} \text { palsy }-10 \\
\text { brain necrosis }-7\end{array}$ & NR \\
\hline $\begin{array}{l}\text { Koutcher et al. } \\
{[58]}\end{array}$ & 29 & 45 & $\begin{array}{l}\text { (median } \\
45-59.4)^{\mathrm{a}}\end{array}$ & 45 & 5 & $\begin{array}{l}52 \\
(\mathrm{LCR})\end{array}$ & 60 & $\begin{array}{l}\text { CN palsy - } 7 \\
\text { TLN - } 14\end{array}$ & NR \\
\hline Karam et al. [59] & 27 & 23 & $\begin{array}{l}44-59.4 \\
\text { (mean 51) }\end{array}$ & 36 & 3 & $\begin{array}{l}53 \\
(\mathrm{LCR})\end{array}$ & {$[49]^{c}$} & $\begin{array}{l}\text { mucosal necrosis }-0 \\
\text { CN palsy }-7 \\
\text { TLN }-0\end{array}$ & 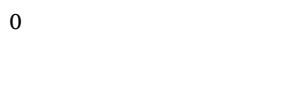 \\
\hline Chan et al. [16] & 38 & 100 & $50-64.8^{\mathrm{d}}$ & 48 & 3 & $\begin{array}{l}44 \\
(\mathrm{LCR})\end{array}$ & 47 & $\begin{array}{l}\text { mucosal necrosis }-23 \\
\text { TLN - } 24 \\
\text { dysphagia }-24 \\
\text { massive epistaxis - } \\
20\end{array}$ & massive epistaxis - 8 \\
\hline Lee et al. [60] & 20 & 100 & $60-64.8^{\mathrm{d}}$ & 45 & 3 & $\begin{array}{l}{[<26 \%]^{\mathrm{c}}} \\
\text { (LFFS) }\end{array}$ & {$[35]^{\mathrm{c}}$} & $\begin{array}{l}\text { brain necrosis - } 20 \\
\text { aspiration }-30 \\
\text { massive epistaxis - } 15\end{array}$ & massive epistaxis - 15 \\
\hline $\mathrm{Ng}$ et al. [61] & 32 & 100 & 60 & 29 & 3 & $\begin{array}{l}45 \\
(\mathrm{LCR})\end{array}$ & 64 & $\begin{array}{l}\text { mucosal necrosis - } 15 \\
\text { TLN - } 31 \\
\text { CN palsy - } 31 \\
\text { dysphagia - } 15 \\
\text { massive epistaxis }-12\end{array}$ & $\begin{array}{l}\text { massive epistaxis }-8 \\
\text { TLN }-1\end{array}$ \\
\hline
\end{tabular}

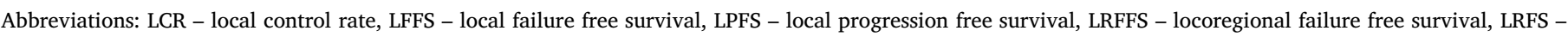
local recurrence free survival, LRRFS - locoregional recurrence free survival, NR - not reported, OS - overall survival.

a Some patients had additional stereotactic radiotherapy or brachytherapy boosting.

b 5 year.

c Estimated figure.

d 1.2 Gy per fraction, twice daily.

e $83 \%$ IMRT.

complications are not uncommon, especially in series delivering a high total dose $(\geq 70 \mathrm{~Gy})$ for the second course of RT. The commonest catastrophic toxicities include carotid blowout, temporal lobe necrosis, mucosal necrosis and aspiration pneumonia. Given the narrow therapeutic margin, it is important to note that a higher radiation dose may not lead to higher chance of survival as fatal complications negate the benefit of higher tumor control rates.

Due attention should also be paid to the allowable maximal tolerated dose for neurologic OARs in the second course of radiotherapy. Several models have been proposed based on the partial recovery from the first course of treatment by approximately $50 \%$ (provided that the first course was delivered more than 1 year ago) [62,63], total cumulative radiation dose $[64,65]$ and the time interval between the two courses of radiotherapy $[66,67]$. However, all of these models are based on rather scanty clinical information, and details of dose distribution within the OARs are largely unknown. Hence the OARs tolerance in the second course of treatment should always be guided by the "As Low As Reasonably Practicable" principles. Similar consideration also apply to the design of re-irradiation volume, and elective treatment (such as the uninvolved regional nodal basin or the subclinical disease in the vicinity of rGTV) is generally not recommended as reported in other locally recurrent head-and-neck squamous cell carcinoma (SCCHN) [68], and the treatment targets usually consist of the rGTV with tight margin only. 
Table 4

Recent reports on stereotactic radiotherapy for recurrent nasopharyngeal carcinoma.

\begin{tabular}{|c|c|c|c|c|c|c|c|c|c|}
\hline Author & No. of patients & $\%$ rT3-4 & Dose & $\begin{array}{l}\text { Median } \\
\text { FU } \\
\text { (months) }\end{array}$ & Endpoint (year) & $\begin{array}{l}\text { Local control } \\
(\%)\end{array}$ & $\begin{array}{l}\text { OS } \\
(\%)\end{array}$ & Severe complications & Fatal complication \\
\hline Dizman et al. [69] & $24^{*}$ & $42 \%$ & $5-6 \mathrm{~Gy} / \mathrm{fr}, 5 \mathrm{fr}$ & 20 & 3 & 21 & 31 & $4 \%$ TLN & $4 \%$ \\
\hline Ozyigit et al. [70] & 24 & $71 \%$ & $6 \mathrm{~Gy} / \mathrm{fr}, 5 \mathrm{fr}$ & 23 & 2 & 82 & NR & $\begin{array}{l}12 \% \text { cranial neuropathies, } \\
4 \% \text { TLN, } \\
17 \% \text { carotid blowout }\end{array}$ & $12.5 \%$ \\
\hline Seo et al. [71] & $35^{* *}$ & $43 \%$ & $7.5-12 \mathrm{~Gy} / \mathrm{fr}, 3-5 \mathrm{fr}$ & 25 & 5 & 79 & 60 & $\begin{array}{l}6 \% \text { mucosal necrosis, } \\
9 \% \text { NP hemorrhage }\end{array}$ & $6 \%$ \\
\hline Leung et al. [72] & 30 & $30 \%$ & $2.5-4.5 \mathrm{~Gy} / \mathrm{fr}, 8-22 \mathrm{fr}$ & 47 & 5 & 57 & 40 & $\begin{array}{l}23 \% \text { cranial neuropathies, } \\
20 \% \text { TLN }\end{array}$ & $3 \%$ \\
\hline \multirow[t]{2}{*}{ Chua et al. [73] } & $43^{k+2 k}$ & $30 \%$ & $8-18 \mathrm{~Gy}$ in single fr & 40 & 3 & 51 & 66 & $\begin{array}{l}16 \% \text { brain necrosis } \\
2 \% \text { NP hemorrhage }\end{array}$ & $0 \%$ \\
\hline & $43^{k+2 \times n}$ & $30 \%$ & $20-49 \mathrm{~Gy}$ in $4-6 \mathrm{fr}$ & 24 & 3 & 83 & 61 & $\begin{array}{l}12 \% \text { brain necrosis } \\
4 \% \text { NP hemorrhage }\end{array}$ & $7 \%$ \\
\hline
\end{tabular}

Abbreviations: fr - fraction, NP - nasopharyngeal, TLN - temporal lobe necrosis.

* $29 \%$ had metastatic disease.

** $9 \%$ - no records for the evaluation of the toxicity data.

$* * * 44 \%$ - persistent disease.

Another commonly employed precision treatment technique for locally recurrent NPC is SRT. Table 4 summarizes the published series reported since our last review [1,69-73]. The number of patients treated with this technique is too small for robust comparisons with IMRT [69-75]. This is still considered a technical approach that remains under development.

The availability of IMPT in recent years, a technique which is characterized by its unique beam properties of a Bragg peak followed by a rapid distal fall-off, has optimized the physical dose distribution and OAR sparing [76]. A study by Lin et al. [77], using IMPT to doses of 59.4-70.2 cobalt gray equivalent in 16 patients with recurrent NPC (12 of whom had rT4 disease), reported 50\% OS and loco-regional PFS at 2 years, with low doses ( $0-22$ Gy) given to the critical OARs resulting in minimal side effects to central nervous system structures. On the other hand, Feehan et al., using heavy charged particles to a median dose of 50 Gy equivalent in 11 patients with recurrent T3-4 NPC, reported less remarkable results [78]: at a median follow up of 28 months, the local control rate was $45 \%$, but temporal lobe necrosis (TLN) and serious aneurysmal bleeding were observed in $36 \%$ and $9 \%$ of patients, respectively. No long-term outcomes and side effects were subsequently reported for these two series. The study by Hu et al., using carbon ions to doses of 50-66 Gy equivalent in 75 patients with recurrent NPC [79], reported an encouraging $87 \%$ local recurrence-free survival at one year, but the median follow-up was only 15 months and longer observation seems warranted. Furthermore, mucosal necrosis and TLN were observed in $9.3 \%$ and $1.3 \%$ of patients respectively, demonstrating that the NP mucosa will be a key dose limiting factor with particle beam therapy.

One of the most important considerations associated with re-irradiation is the risk and the severity of RT-related toxicities. According to a recent meta-analysis [30], grade 5 toxicities were observed in $33 \%$ of patients, with the most common severe effects being mucosal necrosis and massive hemorrhage, followed by feeding difficulties and radiation encephalopathy $[30,56]$.

Carotid blowout is one of the major causes of treatment-related deaths. A literature-based systematic review by McDonald et al. on 1554 patients reported a crude incidence rate of $2.6 \%$ following reirradiation to the head and neck region, and the mortality rate was $76 \%$ [80]. The reported rate of hemorrhage after re-irradiation for NPC has varied widely: the incidence after IMRT or SRT ranges from 0 to $25 \%$. $[54,70,71,81]$ Apart from the dose to the carotid artery [82], the total re-irradiation dose is also an important factor. In a phase 2 randomized study by Tian et al. in which two IMRT dose regimens in recurrent NPC were compared [55], the massive hemorrhage rate at a median followup of 25 months was $19 \%$ in the group given $60 \mathrm{~Gy}$ in 27 fractions as compared with $31 \%$ in the group given $68 \mathrm{~Gy}$ in 34 fractions; the prior radiotherapy dose was the same in the two groups.

Mucosal and adjacent soft tissue/bone necrosis is frequently observed after re-irradiation, causing foul odor, intense headache, and/or profuse bleeding. Endoscopic examination showed extensive areas of crusting, necrotic tissue and even exposed bone. This can also give rise to massive nasal bleeding similar to the carotid blowout syndrome. The reported incidence ranged from $6.3 \%$ to $40.6 \%[49,51,54,55]$. In the study reported by Yu et al. on 204 patients [83], lethal nasopharyngeal necrosis (LNN) was observed in 31 patients (15.2\%). Logistic regression analysis revealed several independent risk factors for LNN: including the female sex, presence of necrosis before re-irradiation, accumulated total prescription dose to GTV $\geq 145.5 \mathrm{~Gy}$, and recurrent tumor volume $\geq 25.38 \mathrm{~cm}^{3}$. A curative-intent endoscopic necrectomy followed by reconstruction using the posterior pedicle nasal septum and floor mucoperiosteum flap was recently described as a safe and effective treatment for post-radiation nasopharyngeal necrosis [84].

Dysphagia is another common RT-related toxicity. The cause of dysphagia can be related to trismus, pharyngeal constrictor muscle dysfunction and/or cranial nerve (IX-XII) injury. Chen et al. reported that $20 \%$ of patients required long term feeding tube insertion or gastrostomy due to severe dysphagia after re-irradiation [54]. Other series have reported severe trismus rates of around 15\% [51,55,58].

Last but not least, TLN is another serious late toxicity that is potentially life-threatening. While some patients may be asymptomatic especially at the early stage, others progressively develop debilitating symptoms including headache, dizziness, memory loss, epilepsy, pressure symptoms, changes in consciousness and/or occasional intracranial hemorrhage [85]. The incidence of TLN is much higher in the re-irradiation cohort than that of single-course RT, ranging from $7 \%$ to $35 \%$. $[49,53-55,58,86]$ Risk factors for TLN include the fractional dose, the cumulative dose, the technique of RT and the time interval between the 2 RT courses [87-90]. The study by Liu et al. on over 200 recurrent NPC patients re-irradiated to around $70 \mathrm{~Gy}$ revealed a $31 \%$ risk of TLN with a median latency period of only 15 months [91]; a maximum cumulative dose of less than $125 \mathrm{~Gy}$ (calculated as equivalent dose in $2 \mathrm{~Gy}$ fractions (EQD2)) and an intervening treatment interval of at least 2 years from prior radiation were recommended.

\section{Role of systemic treatment}

Despite the lack of high-level evidence, induction and/or concurrent chemotherapy is often given with re-irradiation. Induction chemotherapy is especially considered in patients with rT3-4 diseases because this may down-size the recurrent tumor bulk facilitating easier 
Table 5

Adverse prognostic factors affecting the outcomes of recurrent nasopharyngeal carcinoma after re-irradiation.

\begin{tabular}{|c|c|c|c|c|c|}
\hline & Han et al. [49] & Li et al. [107] & Leong et al. [30]* & Tian et al. [108] & Yue et al. [109] \\
\hline Gender & NR & NR & NR & NR & No association \\
\hline Age & Age $>46$ & Increasing age & NR & Age $>50$ & No association \\
\hline Performance status & NR & NR & NR & $\mathrm{KPS} \leq 70$ & NR \\
\hline Time to recur & $\mathrm{NR}$ & $\mathrm{NR}$ & $<36$ months & $\mathrm{NR}$ & No association \\
\hline rT category & Increasing $\mathrm{rT}$ & rT3-4 & rT3-4 & rT3-4 & Increasing $\mathrm{rT}$ \\
\hline rGTV & $>38 \mathrm{cc}$ & Increasing rGTV & NR & $>30 \mathrm{cc}$ & Increasing rGTV \\
\hline $\mathrm{rN}+$ & $\mathrm{rN}+$ & NR & High nodal burden & $\mathrm{rN}+$ & No association \\
\hline 2nd course RT dose & NR & $\geq 68 \mathrm{~Gy}$ & $\mathrm{NR}$ & NR & No association \\
\hline Mean fractional dose & $<2.3 \mathrm{~Gy}$ & $\mathrm{NR}$ & NR & $\mathrm{NR}$ & NR \\
\hline Prior RT complications & NR & Presence of $\geq$ G3 toxicities & NR & Presence of late complications & NR \\
\hline Addition of chemotherapy & NR & NR & No association & NR & No association \\
\hline
\end{tabular}

Abbreviations: GTV - gross tumor volume, KPS - Karnofsky performance status, NR - not reported, RT - radiotherapy.

* Reirradiaton dose $\geq 70$ Gy to rGTV was not associated with improved survival.

sparing of adjacent OARs and eradicate micro-metastases. Concurrent chemotherapy may improve radio-sensitivity leading to improved local tumor control. However, the potential aggravating effect of chemotherapy related to increased late toxicities should also be addressed. It is also unclear whether chemotherapy can be safely sequenced or combined with stereotactic or other hypofractionated or accelerated forms of re-irradiation.

Various chemotherapy agents and their combinations have been investigated in the locally recurrent setting, including cisplatin [58,92], 5-fluorouracil [92], gemcitabine [93] and taxanes [61]. Targeted agents such as anti-epidermal growth factor receptor agents [61,94] have also been tried, though no study has been reported with anti-angiogenic agents due to the underlying risk of hemorrhagic complications for locally recurrent tumors. In fact, in the study reported by Hui et al. on thirteen NPC patients who were treated with sunitinib and had previously been given high-dose radiation to upper aerodigestive tract, a high incidence $(64 \%)$ of hemorrhagic events was found, and it appeared that direct vascular invasion by tumors (which is not uncommon in the locally recurrent setting) further increased the risk of serious bleeding [95]. Hence, the study of anti-angiogenic agents is now mainly confined to use in the distant metastatic setting [96]. On the other hand, the HKNPCSG has reported a study aiming to evaluate the effect of induction docetaxel, cisplatin, and fluorouracil (TPF) followed by weekly docetaxel and cetuximab given concurrently with IMRT on the overall treatment outcomes among a group of rT3-4 patients without distant metastasis. While the proposed regimen achieved a superior treatment outcome (3-year PFS and OS rates of $36 \%$ and $64 \%$, respectively) compared with results seen in previous studies, the poor tolerability of induction TPF and the high rate of TLN (31\%) will impose limitations on its applicability [61].

Another proposed approach suggests treatment of advanced recurrent disease with chemotherapy alone [97]. A case-control study on 88 rT3-4 N0-1 NPC patients treated with chemotherapy with or without re-RT reported no statistical significance in the 5-year survival rates between the two groups ( $27.5 \%$ vs $23.4 \%$ ), suggesting the possibility of sole use of chemotherapy in conservative settings.

No ongoing studies focus on the emerging role of immunotherapy in locally recurrent NPC. Promising results have been reported with pembrolizumab, nivolumab, and camrelizumab in the second-line setting (overall response rate 20-34\%) [98-100] or in combination with chemotherapy (overall response rate 91\%) [100]. However, all of these studies comprise small series of mixed groups with distant metastases and/or local-regional recurrence. Therefore, the exact role of immunotherapy in the management of locally recurrent NPC remains yet to be evaluated. The observed long-term disease control in some patients with recurrent or metastatic SCCHN [101,102] warrants investigation of immunotherapy as a single modality or in combination with radiation therapy in the treatment of locally recurrent disease. Studies are currently combining re-irradiation with immune check point inhibitors in the treatment of recurrent SCCHN including NPC (NCT03521570). Other novel strategies including adoptive immunotherapy [103] and therapeutic vaccine [104] are also under active investigation.

Prognostic factors

\section{Surgery}

Several important adverse prognostic factors have been identified in patients receiving surgery. These include advanced $\mathrm{T}$ category, large tumor size, positive resection margins, presence of gross tumor in the sphenoid sinus, cavernous sinus invasion and synchronous cervical nodal metastasis $[48,105]$. Further modifications based on resectability have been proposed regarding T category [106]. Specifically, resectable rT2 and resectable rT3 were defined as tumor being confined to the superficial parapharyngeal space, and tumor confined to the base of sphenoid sinus.

A meta-analysis in 2014 involving 779 patients with locally recurrent NPC showed that endoscopic surgery was superior to open surgery in selected patients with T3/4 disease. In addition, this study showed that adjuvant re-irradiation achieved additional survival advantages when compared with surgery alone [48].

\section{Radiotherapy}

In a prognostic model proposed by Li et al. [107], five significant prognostic factors for OS in patients with locally recurrent NPC were identified: age, T-category of the recurrence (rT3-4), size of rGTV, presence of prior RT-induced grade 3 or above toxicities, and the dose of re-irradiation by IMRT (EQD2 of $\geq 68 \mathrm{~Gy}$ ). A prognostic index (PI) was constructed based on these five factors. A PI score of 252 consistently categorizes patients into good vs poor risk for OS and grade five toxicities. This may serve as a useful model to guide clinicians and patients making decisions about re-irradiation. Table 5 summarizes other factors that influence the outcomes of recurrent NPC as reported by various studies $[30,49,107-109]$. Recurrent $\mathrm{T}$ category and tumor size are the most consistent prognostic risk factors.

\section{Treatment outcomes}

The management strategy outlined above is the most commonly adopted practice in Hong Kong, as shown in a recent Patterns of Care study reported by the HKNPCSG [110]. The study included 272 locally recurrent non-metastatic NPC patients who were treated with a primary course of IMRT: their rT stage distribution was 30.5\%, 9.6\%, 25.4\% and $34.6 \%$ for rT1, rT2, rT3 and rT4, respectively. Among these patients, $30.9 \%$ were treated with radical surgery \pm adjuvant RT or chemotherapy, $35.7 \%$ with re-RT \pm induction or concurrent chemotherapy, $23.2 \%$ with palliative chemotherapy alone, and $10.3 \%$ were managed with palliative intent with no active treatment given. 


\section{Multidisciplinary Assessments}

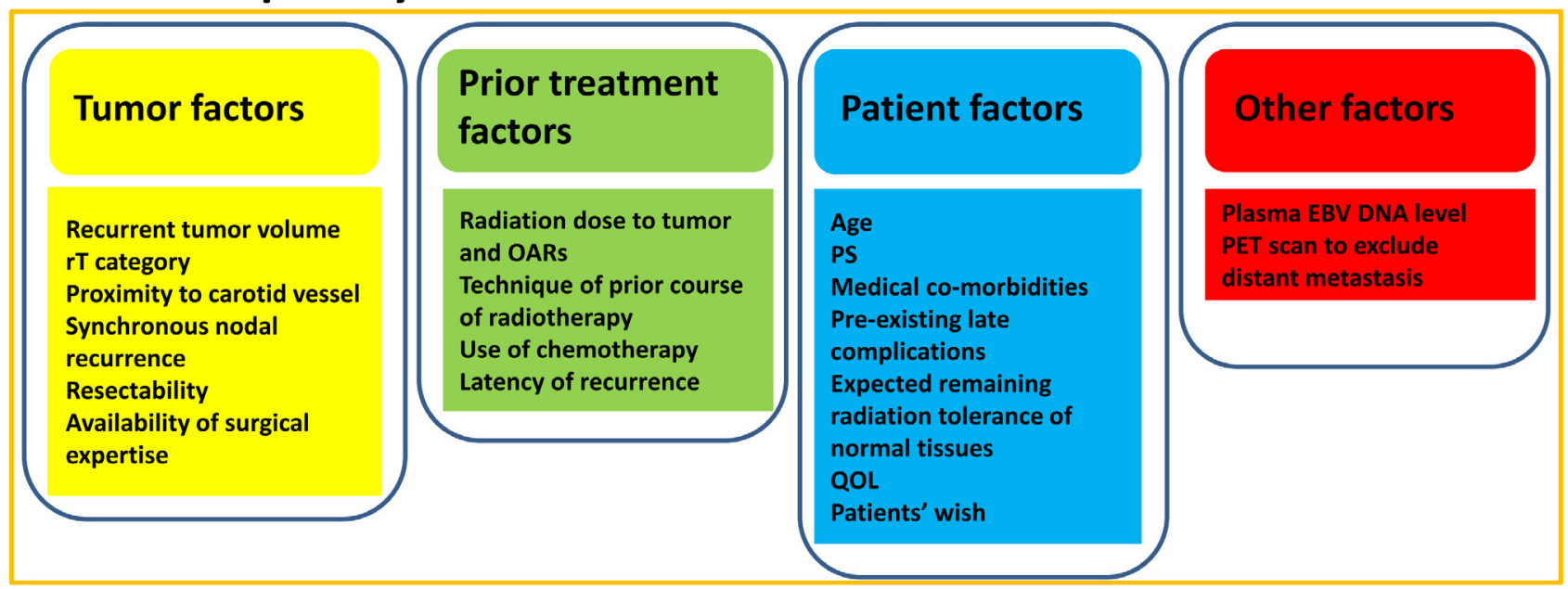

\section{Treatment Considerations}

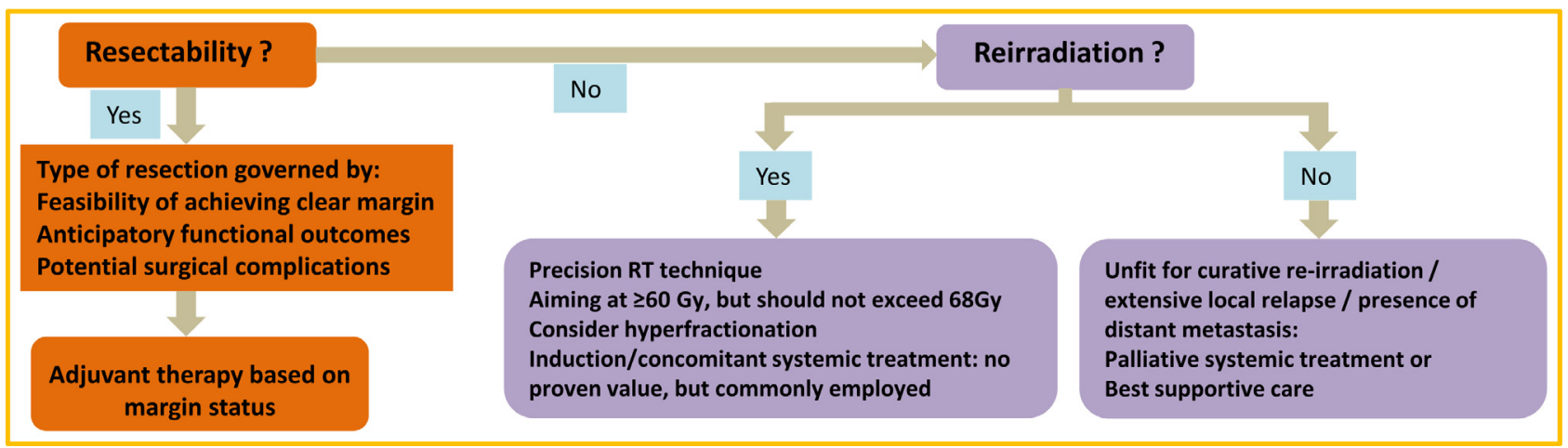

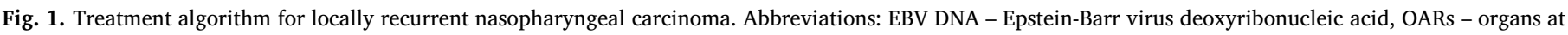
risk, PET - positron emission tomography, PS - performance status, QOL - quality of life.

The most common treatment modality for recurrent stage I, II, III and IV diseases was surgery $(82.3 \%)$, surgery $(38.1 \%)$ or re-RT $(38.1 \%)$, re-RT (52.1\%), and chemotherapy alone (42.3\%), respectively. The 5-year OS for the whole series was $30.2 \%$, and the corresponding 5 -year OS for patients who received surgery, re-RT, chemotherapy or no active treatment was $56.3 \%, 21.8 \%, 11.6 \%$ and $11.1 \%$, respectively. Our results indicate favorable long-term outcomes with surgery for a resectable recurrence, while re-RT will achieve a two-fold OS improvement compared against chemotherapy or no active treatment.

\section{Treatment algorithm and follow up}

The appropriate treatment algorithm for patients with locally recurrent NPC is described in detail in Fig. 1. Multidisciplinary assessment with comprehensive consideration of all factors (including recurrent tumor factors, prior treatment factors and patient factors), and an in-depth discussion with the affected patient are important for treatment decisions. Salvage surgery should be considered whenever feasible, while re-irradiation should be considered for patients with unresectable disease, or those who are unsuitable or reluctant for surgery. For patients with extensive recurrences, it is impossible to attain adequate therapeutic dose coverage using re-irradiation due to the limited remaining tolerance of critical OARs; treatment by chemotherapy and/or immunotherapy is an alternative option.

After radical salvage treatment, follow-up is similar to that recommended by the NCCN [111] and ESMO [8] guidelines as in the setting of primary treatment. This consists of a combination of periodic clinical and radiological assessment. Clinical examination of the nasopharynx and neck, cranial nerve function, fiberoptic endoscopy, and evaluation for the presence of systemic symptoms are performed at approximately every 3 months in the first 2 years, half-yearly at 3-5 years after treatment, and annually thereafter. MRI should also be performed every 6-12 months not only for surveillance of the local disease but also the detection of late complications. Patients are also regularly reviewed by nurse specialists and relevant allied health professionals for supportive care, rehabilitation of speech, hearing, swallowing function, and monitoring of nutritional status.

\section{Future directions}

Recent advances in robotic surgery and 3D-endoscopic visualization have enhanced surgical feasibility and accessibility. The Da Vinci robotic surgical system provides a magnified, three-dimensional view of the surgical field, and thus facilitates more precise surgical dissection with the possibility of three-handed manipulation. The next-generation flexible robotic surgical systems further improve the access to the nasopharynx, avoiding the need to split the soft palate and enabling simultaneous manipulation of four instruments (three surgical instruments and a camera) into the NP without collision or restriction of the surgeons' joint movement [112]. Furthermore, anecdotal series on photodynamic therapy suggest that this form of treatment may also play a role in the salvage of superficial NP recurrence [113-115].

Integration of RT with immunotherapy has been proposed with promising preclinical data of radiosensitization by immune checkpoint blockade therapies [116]. The newly launched HKNPCSG trial will examine this concept in further scope, by combining re-irradiation with 
avelumab for unresectable localized recurrent NPC. Better understanding of the tolerance of key OARs is obviously important for optimizing dose-fractionation schedules for re-irradiation. Previous publications by Yu et al. and IHNSG have provided useful summary data for both mucosal [49] and carotid artery tolerances [117]. Photobiomodulation therapy using light therapy (lasers or LEDs) [118] has shown promising potential to promote mucosal healing through biostimulation of cellular repair, angiogenesis, and its anti-inflammatory effects. Preliminary evidence suggests that this can potentiate a clinically effective treatment for post-irradiation mucosal necrosis. Other strategies including hyperbaric oxygen [119] and tissue grafting [84] have been described and further studies are warranted.

\section{Conclusion}

The evolution of the management of NPC has been very impressive. High rates of local disease control have been achieved though both technological improvements and oncological research. Paradoxically this success has now made treatment of local recurrences extremely challenging. This review summarizes the current clinical options, with ongoing research targeting radioresistance and further technological advances awaited.

\section{Declaration of Competing Interest}

The authors declare that there is no conflict of interest related to this review.

\section{References}

[1] Suarez C, Rodrigo JP, Rinaldo A, Langendijk JA, Shaha AR, Ferlito A. Current treatment options for recurrent nasopharyngeal cancer. Eur Arch Otorhinolaryngol 2010;267:1811-24.

[2] Lee AW, Ma BB, Ng WT, Chan AT. Management of nasopharyngeal carcinoma: current practice and future perspective. J Clin Oncol 2015;33:3356-64.

[3] Chua ML, Wee JT, Hui EP, Chan AT. Nasopharyngeal carcinoma. Lancet 2016;387:1012-24.

[4] Au KH, Ngan RKC, Ng AWY, Poon DMC, Ng WT, Yuen KT, et al. Treatment outcomes of nasopharyngeal carcinoma in modern era after intensity modulated radiotherapy (IMRT) in Hong Kong: a report of 3328 patients (HKNPCSG 1301 study). Oral Oncol 2018;77:16-21.

[5] Ng WT, Lee MC, Hung WM, Choi CW, Lee KC, Chan OS, et al. Clinical outcomes and patterns of failure after intensity-modulated radiotherapy for nasopharyngeal carcinoma. Int J Radiat Oncol Biol Phys 2011;79:420-8.

[6] Li JX, Huang SM, Jiang XH, Ouyang B, Han F, Liu S, et al. Local failure patterns for patients with nasopharyngeal carcinoma after intensity-modulated radiotherapy. Radiat Oncol. 2014;9:87.

[7] Kong L, Wang L, Shen C, Hu C, Wang L, Lu JJ. Salvage intensity-modulated radiation therapy (IMRT) for locally recurrent nasopharyngeal cancer after definitive IMRT: a novel scenario of the modern era. Sci Rep 2016;6:32883.

[8] Chan AT, Gregoire V, Lefebvre JL, Licitra L, Hui EP, Leung SF, et al. Nasopharyngeal cancer: EHNS-ESMO-ESTRO clinical practice guidelines for diagnosis, treatment and follow-up. Ann Oncol 2012;23;Suppl 7:vii83-5.

[9] Wang WH, Lin YC, Chen WC, Chen MF, Chen CC, Lee KF. Detection of mucosal recurrent nasopharyngeal carcinomas after radiotherapy with narrow-band imaging endoscopy. Int J Radiat Oncol Biol Phys 2012;83:1213-9.

[10] Abdel Khalek Abdel Razek A, King A. MRI and CT of nasopharyngeal carcinoma. AJR Am J Roentgenol 2012;198:11-8.

[11] Lin GW, Wang LX, Ji M, Qian HZ. The use of MR imaging to detect residual versus recurrent nasopharyngeal carcinoma following treatment with radiation therapy. Eur J Radiol 2013;82:2240-6.

[12] Ng SH, Chan SC, Yen TC, Liao CT, Chang JT, Ko SF, et al. Comprehensive imaging of residual/ recurrent nasopharyngeal carcinoma using whole-body MRI at $3 \mathrm{~T}$ compared with FDG-PET-CT. Eur Radiol 2010;20:2229-40.

[13] Lai V, Li X, Lee VH, Lam KO, Chan Q, Khong PL. Intravoxel incoherent motion MR imaging: comparison of diffusion and perfusion characteristics between nasopharyngeal carcinoma and post-chemoradiation fibrosis. Eur Radiol 2013;23:2793-801.

[14] Mao J, Shen J, Yang Q, Yu T, Duan X, Zhong J, et al. Intravoxel incoherent motion MRI in differentiation between recurrent carcinoma and postchemoradiation fibrosis of the skull base in patients with nasopharyngeal carcinoma. J Magn Reson Imaging 2016:44:1556-64.

[15] Lee AW, Law SC, Foo W, Poon YF, Cheung FK, Chan DK, et al. Retrospective analysis of patients with nasopharyngeal carcinoma treated during 1976-1985: survival after local recurrence. Int J Radiat Oncol Biol Phys 1993;26:773-82.

[16] Chan OS, Sze HC, Lee MC, Chan LL, Chang AT, Lee SW, et al. Reirradiation with intensity-modulated radiotherapy for locally recurrent T3 to T4 nasopharyngeal carcinoma. Head Neck 2017;39:533-40.

[17] Yen RF, Hung RL, Pan MH, Wang YH, Huang KM, Lui LT, et al. 18-fluoro-2deoxyglucose positron emission tomography in detecting residual/recurrent nasopharyngeal carcinomas and comparison with magnetic resonance imaging. Cancer 2003;98:283-7.

[18] Wei J, Pei S, Zhu X. Comparison of 18F-FDG PET/CT, MRI and SPECT in the diagnosis of local residual/recurrent nasopharyngeal carcinoma: a meta-analysis. Oral Oncol 2016;52:11-7.

[19] Wang WY, Twu CW, Lin WY, Jiang RS, Liang KL, Chen KW, et al. Plasma epsteinbarr virus DNA screening followed by (18) F-fluoro-2-deoxy-D-glucose positron emission tomography in detecting posttreatment failures of nasopharyngeal carcinoma. Cancer 2011.

[20] Hong RL, Lin CY, Ting LL, Ko JY, Hsu MM. Comparison of clinical and molecular surveillance in patients with advanced nasopharyngeal carcinoma after primary therapy: the potential role of quantitative analysis of circulating Epstein-Barr virus DNA. Cancer 2004;100:1429-37.

[21] Hou X, Zhao C, Guo Y, Han F, Lu LX, Wu SX, et al. Different clinical significance of pre- and post-treatment plasma Epstein-Barr virus DNA load in nasopharyngeal carcinoma treated with radiotherapy. Clin Oncol (R Coll Radiol) 2011:23:128-33.

[22] Chai SJ, Pua KC, Saleh A, Yap YY, Lim PV, Subramaniam SK, et al. Clinical significance of plasma Epstein-Barr Virus DNA loads in a large cohort of Malaysian patients with nasopharyngeal carcinoma. J Clin Virol 2012;55:34-9.

[23] Leung SF, Lo YM, Chan AT, To KF, To E, Chan LY, et al. Disparity of sensitivities in detection of radiation-naive and postirradiation recurrent nasopharyngeal carcinoma of the undifferentiated type by quantitative analysis of circulating EpsteinBarr virus DNA1,2. Clin Cancer Res 2003;9:3431-4.

[24] Hsu CL, Chan SC, Chang KP, Lin TL, Lin CY, Hsieh CH, et al. Clinical scenario of EBV DNA follow-up in patients of treated localized nasopharyngeal carcinoma. Oral Oncol 2013;49:620-5.

[25] Chan JY, Wong ST. The role of plasma Epstein-Barr virus DNA in the management of recurrent nasopharyngeal carcinoma. Laryngoscope 2014;124:126-30.

[26] Lam JW, Chan JY, Ho WK, Tsang RK. Use of transoral nasopharyngeal brush biopsy for Epstein-Barr virus DNA detection of local recurrence of nasopharyngeal carcinoma after radiotherapy. Head Neck 2016;38(Suppl 1):E1301-4.

[27] Hao SP, Tsang NM, Chang KP. Monitoring tumor recurrence with nasopharyngeal swab and latent membrane protein-1 and epstein-barr nuclear antigen-1 gene detection in treated patients with nasopharyngeal carcinoma. Laryngoscope 2004;114:2027-30.

[28] Lee AW, Fee Jr. WE, Ng WT, Chan LK. Nasopharyngeal carcinoma: salvage of local recurrence. Oral Oncol 2012;48:768-74.

[29] You R, Zou X, Hua YJ, Han F, Li L, Zhao C, et al. Salvage endoscopic nasopharyngectomy is superior to intensity-modulated radiation therapy for local recurrence of selected T1-T3 nasopharyngeal carcinoma - a case-matched comparison. Radiother Oncol 2015;115:399-406.

[30] Leong YH, Soon YY, Lee KM, Wong LC, Tham IWK, Ho FCH. Long-term outcomes after reirradiation in nasopharyngeal carcinoma with intensity-modulated radiotherapy: a meta-analysis. Head Neck 2018;40:622-31.

[31] Tsang RK, Ho WK, Wei WI, Chan JY. Transoral robotic assisted nasopharyngectomy via a lateral palatal flap approach. Laryngoscope 2013;123:2180-3.

[32] Chan JY. Surgical management of recurrent nasopharyngeal carcinoma. Oral Oncol 2014;50:913-7.

[33] Chan JYW, Wong STS, Wei WI. Surgical salvage of recurrent T3 nasopharyngeal carcinoma: prognostic significance of clivus, maxillary, temporal and sphenoid bone invasion. Oral Oncol 2019;91:85-91.

[34] Chan JYW, Wong STS, Wei WI. Stage II recurrent nasopharyngeal carcinoma: Prognostic significance of retropharyngeal nodal metastasis, parapharyngeal invasion, and carotid encasement. Head Neck 2018;40:103-10.

[35] Ng WT, Wong ECY, Lee VHF, Chan JYW, Lee AWM. Head and neck cancer in Hong Kong. Jpn J Clin Oncol 2018;48:13-21.

[36] King WW, Ku PK, Mok CO, Teo PM. Nasopharyngectomy in the treatment of recurrent nasopharyngeal carcinoma: a twelve-year experience. Head Neck 2000;22:215-22.

[37] Fee Jr. WE, Moir MS, Choi EC, Goffinet D. Nasopharyngectomy for recurrent nasopharyngeal cancer: a 2- to 17-year follow-up. Arch Otolaryngol Head Neck Surg 2002;128:280-4.

[38] Hao SP, Tsang NM, Chang KP, Hsu YS, Chen CK, Fang KH. Nasopharyngectomy for recurrent nasopharyngeal carcinoma: a review of 53 patients and prognostic factors. Acta Otolaryngol 2008;128:473-81.

[39] Vlantis AC, Chan HS, Tong MC, Yu BK, Kam MK, van Hasselt CA. Surgical salvage nasopharyngectomy for recurrent nasopharyngeal carcinoma: a multivariate analysis of prognostic factors. Head Neck 2011;33:1126-31.

[40] Wei WI, Chan JY, Ng RW, Ho WK. Surgical salvage of persistent or recurrent nasopharyngeal carcinoma with maxillary swing approach - critical appraisal after 2 decades. Head Neck 2011;33:969-75.

[41] Bian X, Chen H, Liao L. A retrospective study of salvage surgery for recurrent nasopharyngeal carcinoma. Int J Clin Oncol 2012;17:212-7.

[42] Ng LS, Lim CM, Loh KS. Long-term outcomes of nasopharyngectomy using partial maxillectomy approach. Laryngoscope 2016;126:1103-7.

[43] Chen MY, Wen WP, Guo X, Yang AK, Qian CN, Hua YJ, et al. Endoscopic nasopharyngectomy for locally recurrent nasopharyngeal carcinoma. Laryngoscope 2009;119:516-22.

[44] Ko JY, Wang CP, Ting LL, Yang TL, Tan CT. Endoscopic nasopharyngectomy with potassium-titanyl-phosphate (KTP) laser for early locally recurrent nasopharyngeal carcinoma. Head Neck 2009;31:1309-15.

[45] Zou X, Han F, Ma WJ, Deng MQ, Jiang R, Guo L, et al. Salvage endoscopic 
nasopharyngectomy and intensity-modulated radiotherapy versus conventional radiotherapy in treating locally recurrent nasopharyngeal carcinoma. Head Neck 2015;37:1108-15.

[46] Liu J, Yu H, Sun X, Wang D, Gu Y, Liu Q, et al. Salvage endoscopic nasopharyngectomy for local recurrent or residual nasopharyngeal carcinoma: a 10-year experience. Int J Clin Oncol 2017;22:834-42.

[47] Chan YW, Chow VL, Wei WI. Quality of life of patients after salvage nasopharyngectomy for recurrent nasopharyngeal carcinoma. Cancer 2012;118:3710-8.

[48] Na'ara S, Amit M, Billan S, Cohen JT, Gil Z. Outcome of patients undergoing salvage surgery for recurrent nasopharyngeal carcinoma: a meta-analysis. Ann Surg Oncol 2014;21:3056-62.

[49] Han F, Zhao C, Huang SM, Lu LX, Huang Y, Deng XW, et al. Long-term outcomes and prognostic factors of re-irradiation for locally recurrent nasopharyngeal carcinoma using intensity-modulated radiotherapy. Clin Oncol (R Coll Radiol) 2012;24:569-76.

[50] Hua YJ, Han F, Lu LX, Mai HQ, Guo X, Hong MH, et al. Long-term treatment outcome of recurrent nasopharyngeal carcinoma treated with salvage intensity modulated radiotherapy. Eur J Cancer 2012;48:3422-8.

[51] Qiu S, Lin S, Tham IW, Pan J, Lu J, Lu JJ. Intensity-modulated radiation therapy in the salvage of locally recurrent nasopharyngeal carcinoma. Int J Radiat Oncol Biol Phys 2012;83:676-83.

[52] Qiu S, Lu J, Zheng W, Xu L, Lin S, Huang C, et al. Advantages of intensity modulated radiotherapy in recurrent T1-2 nasopharyngeal carcinoma: a retrospective study. BMC Cancer 2014;14:797.

[53] Chua DT, Sham JS, Leung LH, Au GK. Re-irradiation of nasopharyngeal carcinoma with intensity-modulated radiotherapy. Radiother Oncol 2005;77:290-4.

[54] Chen HY, Ma XM, Ye M, Hou YL, Xie HY, Bai YR. Effectiveness and toxicities of intensity-modulated radiotherapy for patients with locally recurrent nasopharyngeal carcinoma. PLoS One 2013;8:e73918.

[55] Tian YM, Zhao C, Guo Y, Huang Y, Huang SM, Deng XW, et al. Effect of total dose and fraction size on survival of patients with locally recurrent nasopharyngea carcinoma treated with intensity-modulated radiotherapy: a phase 2, single-center, randomized controlled trial. Cancer 2014;120:3502-9.

[56] Tian YM, Huang WZ, Yuan X, Bai L, Zhao C, Han F. The challenge in treating locally recurrent T3-4 nasopharyngeal carcinoma: the survival benefit and severe late toxicities of re-irradiation with intensity-modulated radiotherapy. Oncotarget 2017.

[57] Kong F, Zhou J, Du C, He X, Kong L, Hu C, et al. Long-term survival and late complications of intensity-modulated radiotherapy for recurrent nasopharyngeal carcinoma. BMC Cancer 2018;18:1139.

[58] Koutcher L, Lee N, Zelefsky M, Chan K, Cohen G, Pfister D, et al. Reirradiation of locally recurrent nasopharynx cancer with external beam radiotherapy with or without brachytherapy. Int J Radiat Oncol Biol Phys 2010;76:130-7.

[59] Karam I, Huang SH, McNiven A, Su J, Xu W, Waldron J, et al. Outcomes after reirradiation for recurrent nasopharyngeal carcinoma: North American experience. Head Neck 2016;38(Suppl 1):E1102-9.

[60] Lee VH, Kwong DL, Leung TW, Ng SC, Lam KO, Tong CC, et al. Hyperfractionation compared to standard fractionation in intensity-modulated radiation therapy for patients with locally advanced recurrent nasopharyngeal carcinoma. Eur Arch Otorhinolaryngol 2017;274:1067-78.

[61] Ng WT, Ngan RKC, Kwong DLW, Tung SY, Yuen KT, Kam MKM, et al. Prospective, multicenter, phase 2 trial of induction chemotherapy followed by bio-chemoradiotherapy for locally advanced recurrent nasopharyngeal carcinoma. Int $J$ Radiat Oncol Biol Phys 2018;100:630-8.

[62] Ang KK, Jiang GL, Feng Y, Stephens LC, Tucker SL, Price RE. Extent and kinetics of recovery of occult spinal cord injury. Int J Radiat Oncol Biol Phys 2001;50:1013-20.

[63] Sulman EP, Schwartz DL, Le TT, Ang KK, Morrison WH, Rosenthal DI, et al. IMRT reirradiation of head and neck cancer-disease control and morbidity outcomes. Int J Radiat Oncol Biol Phys 2009;73:399-409.

[64] Lee AW, Foo W, Law SC, Peters LJ, Poon YF, Chappell R, et al. Total biological effect on late reactive tissues following reirradiation for recurrent nasopharyngeal carcinoma. Int J Radiat Oncol Biol Phys 2000;46:865-72.

[65] van der Kogel AJ. Retreatment tolerance of the spinal cord. Int J Radiat Oncol Biol Phys 1993;26:715-7.

[66] Jones B, Hopewell JW. Alternative models for estimating the radiotherapy retreatment dose for the spinal cord. Int J Radiat Biol 2014;90:731-41.

[67] Jones B, Grant W. Retreatment of central nervous system tumours. Clin Oncol ( R Coll Radiol) 2014;26:407-18.

[68] Margalit DN, Wong SJ. Reirradiation for head and neck cancer: the who and the how. Int J Radiat Oncol Biol Phys 2018;100:618-20.

[69] Dizman A, Coskun-Breuneval M, Altinisik-Inan G, Olcay GK, Cetindag MF, Guney Y. Reirradiation with robotic stereotactic body radiotherapy for recurrent nasopharyngeal carcinoma. Asian Pac J Cancer Prev 2014;15:3561-6.

[70] Ozyigit G, Cengiz M, Yazici G, Yildiz F, Gurkaynak M, Zorlu F, et al. A retrospective comparison of robotic stereotactic body radiotherapy and three-dimensional conformal radiotherapy for the reirradiation of locally recurrent nasopharyngeal carcinoma. Int J Radiat Oncol Biol Phys 2011;81(4):e263-8.

[71] Seo Y, Yoo H, Yoo S, Cho C, Yang K, Kim MS, et al. Robotic system-based fractionated stereotactic radiotherapy in locally recurrent nasopharyngeal carcinoma. Radiother Oncol 2009;93:570-4.

[72] Leung TW, Wong VY, Tung SY. Stereotactic radiotherapy for locally recurrent nasopharyngeal carcinoma. Int J Radiat Oncol Biol Phys 2009;75:734-41.

[73] Chua DT, Wu SX, Lee V, Tsang J. Comparison of single versus fractionated dose of stereotactic radiotherapy for salvaging local failures of nasopharyngeal carcinoma: a matched-cohort analysis. Head Neck Oncol 2009;1:13.
[74] Agas RAF, Yu KKL, Sogono PG, Co LBA, Jacinto J, Bacorro WR, et al. Reirradiation for recurrent nasopharyngeal carcinomas: experience from an academic tertiary center in a low- to middle-income country. J Glob Oncol 2019;5:1-14.

[75] Roeder F, Zwicker F, Saleh-Ebrahimi L, Timke C, Thieke C, Bischof M, et al. Intensity modulated or fractionated stereotactic reirradiation in patients with recurrent nasopharyngeal cancer. Radiat Oncol 2011;6:22.

[76] Widesott L, Pierelli A, Fiorino C, Dell'oca I, Broggi S, Cattaneo GM, et al. Intensitymodulated proton therapy versus helical tomotherapy in nasopharynx cancer: planning comparison and NTCP evaluation. Int J Radiat Oncol Biol Phys 2008;72:589-96.

[77] Lin R, Slater JD, Yonemoto LT, Grove RI, Teichman SL, Watt DK, et al. Nasopharyngeal carcinoma: repeat treatment with conformal proton therapy-dose-volume histogram analysis. Radiology 1999;213:489-94.

[78] Feehan PE, Castro JR, Phillips TL, Petti P, Collier JM, Daftari I, et al. Recurrent locally advanced nasopharyngeal carcinoma treated with heavy charged particle irradiation. Int J Radiat Oncol Biol Phys 1992;23:881-4.

[79] Hu J, Bao C, Gao J, Guan X, Hu W, Yang J, et al. Salvage treatment using carbon ion radiation in patients with locoregionally recurrent nasopharyngeal carcinoma: Initial results. Cancer 2018;124:2427-37.

[80] McDonald MW, Moore MG, Johnstone PA. Risk of carotid blowout after reirradiation of the head and neck: a systematic review. Int J Radiat Oncol Biol Phys 2012;82:1083-9.

[81] Benhaim C, Lapeyre M, Thariat J. Stereotactic irradiation in head and neck cancers. Cancer Radiother. 2014;18:280-96.

[82] Gebhardt BJ, Vargo JA, Ling D, Jones B, Mohney M, Clump DA, et al. Carotid dosimetry and the risk of carotid blowout syndrome after reirradiation with head and neck stereotactic body radiation therapy. Int J Radiat Oncol Biol Phys 2018;101:195-200.

[83] Yu YH, Xia WX, Shi JL, Ma WJ, Li Y, Ye YF, et al. A model to predict the risk of lethal nasopharyngeal necrosis after re-irradiation with intensity-modulated radiotherapy in nasopharyngeal carcinoma patients. Chin J Cancer 2016;35:59.

[84] Zou X, Wang SL, Liu YP, Liu YL, Zou RH, Zhang YN, et al. A curative-intent endoscopic surgery for postradiation nasopharyngeal necrosis in patients with nasopharyngeal carcinoma. Cancer Commun (Lond) 2018;38:74.

[85] Lee AW, Kwong DL, Leung SF, Tung SY, Sze WM, Sham JS, et al. Factors affecting risk of symptomatic temporal lobe necrosis: significance of fractional dose and treatment time. Int J Radiat Oncol Biol Phys 2002;53:75-85.

[86] Lee NY, Zhang Q, Pfister DG, Kim J, Garden AS, Mechalakos J, et al. Addition of bevacizumab to standard chemoradiation for locoregionally advanced nasopharyngeal carcinoma (RTOG 0615): a phase 2 multi-institutional trial. Lancet Oncol 2012;13:172-80.

[87] Lee AW, Foo W, Chappell R, Fowler JF, Sze WM, Poon YF, et al. Effect of time, dose, and fractionation on temporal lobe necrosis following radiotherapy for nasopharyngeal carcinoma. Int J Radiat Oncol Biol Phys 1998;40:35-42.

[88] Zhou X, Ou X, Xu T, Wang X, Shen C, Ding J, et al. Effect of dosimetric factors on occurrence and volume of temporal lobe necrosis following intensity modulated radiation therapy for nasopharyngeal carcinoma: a case-control study. Int $\mathrm{J}$ Radiat Oncol Biol Phys 2014;90:261-9.

[89] Chen J, Dassarath M, Yin Z, Liu H, Yang K, Wu G. Radiation induced temporal lobe necrosis in patients with nasopharyngeal carcinoma: a review of new avenues in its management. Radiat Oncol 2011;6:128.

[90] Bakst RL, Lee N, Pfister DG, Zelefsky MJ, Hunt MA, Kraus DH, et al. Hypofractionated dose-painting intensity modulated radiation therapy with chemotherapy for nasopharyngeal carcinoma: a prospective trial. Int J Radiat Oncol Biol Phys 2011;80:148-53.

[91] Liu S, Lu T, Zhao C, Shen J, Tian Y, Guan Y, et al. Temporal lobe injury after reirradiation of locally recurrent nasopharyngeal carcinoma using intensity modulated radiotherapy: clinical characteristics and prognostic factors. J Neurooncol 2014;119:421-8.

[92] Poon D, Yap SP, Wong ZW, Cheung YB, Leong SS, Wee J, et al. Concurrent chemoradiotherapy in locoregionally recurrent nasopharyngeal carcinoma. Int $J$ Radiat Oncol Biol Phys 2004;59:1312-8.

[93] Chua DT, Sham JS, Au GK. Induction chemotherapy with cisplatin and gemcitabine followed by reirradiation for locally recurrent nasopharyngeal carcinoma. Am $\mathrm{J}$ Clin Oncol 2005;28:464-71.

[94] Xu T, Ou X, Shen C, Hu C. Cetuximab in combination with chemoradiotherapy in the treatment of recurrent and/or metastatic nasopharyngeal carcinoma. Anticancer Drugs 2016;27:66-70.

[95] Hui EP, Ma BB, King AD, Mo F, Chan SL, Kam MK, et al. Hemorrhagic complications in a phase II study of sunitinib in patients of nasopharyngeal carcinoma who has previously received high-dose radiation. Ann Oncol 2011;22:1280-7.

[96] Hui EP, Ma BBY, Loong HHF, Mo F, Li L, King AD, et al. Efficacy, safety, and pharmacokinetics of axitinib in nasopharyngeal carcinoma: a preclinical and phase II correlative study. Clin Cancer Res 2018;24:1030-7.

[97] Liu LT, Chen QY, Tang LQ, Zhang L, Guo SS, Guo L, et al. With or without reirradiation in advanced local recurrent nasopharyngeal carcinoma: a case-control study. BMC Cancer. 2016;16:774.

[98] Hsu C, Lee SH, Ejadi S, Even C, Cohen RB, Le Tourneau C, et al. Safety and antitumor activity of pembrolizumab in patients with programmed death-ligand 1 positive nasopharyngeal carcinoma: results of the KEYNOTE-028 study. J Clin Oncol 2017;35:4050-6.

[99] Ma BBY, Lim WT, Goh BC, Hui EP, Lo KW, Pettinger A, et al. Antitumor activity of nivolumab in recurrent and metastatic nasopharyngeal carcinoma: an international, multicenter study of the mayo clinic phase 2 consortium (NCI-9742). J Clin Oncol 2018;36:1412-8.

[100] Fang W, Yang Y, Ma Y, Hong S, Lin L, He X, et al. Camrelizumab (SHR-1210) alone 
or in combination with gemcitabine plus cisplatin for nasopharyngeal carcinoma: results from two single-arm, phase 1 trials. Lancet Oncol 2018;19:1338-50.

[101] Ferris RL, Blumenschein Jr. G, Fayette J, Guigay J, Colevas AD, Licitra L, et al. Nivolumab vs investigator's choice in recurrent or metastatic squamous cell carcinoma of the head and neck: 2-year long-term survival update of CheckMate 141 with analyses by tumor PD-L1 expression. Oral Oncol 2018;81:45-51.

[102] Cohen EEW, Soulieres D, Le Tourneau C, Dinis J, Licitra L, Ahn MJ, et al. Pembrolizumab versus methotrexate, docetaxel, or cetuximab for recurrent or metastatic head-and-neck squamous cell carcinoma (KEYNOTE-040): a randomised, open-label, phase 3 study. Lancet 2019;393:156-67.

[103] Huang J, Fogg M, Wirth LJ, Daley H, Ritz J, Posner MR, et al. Epstein-Barr virusspecific adoptive immunotherapy for recurrent, metastatic nasopharyngeal carcinoma. Cancer 2017;123:2642-50.

[104] Hui EP, Taylor GS, Jia H, Ma BB, Chan SL, Ho R, et al. Phase I trial of recombinant modified vaccinia ankara encoding Epstein-Barr viral tumor antigens in nasopharyngeal carcinoma patients. Cancer Res 2013;73:1676-88.

[105] Chan JY, To VS, Chow VL, Wong ST, Wei WI. Multivariate analysis of prognostic factors for salvage nasopharyngectomy via the maxillary swing approach. Head Neck 2014;36:1013-7.

[106] You R, Zou X, Wang SL, Jiang R, Tang LQ, Zhang WD, et al. New surgical staging system for patients with recurrent nasopharyngeal carcinoma based on the AJCC/ UICC rTNM classification system. Eur J Cancer 2015;51:1771-9.

[107] Li YQ, Tian YM, Tan SH, Liu MZ, Kusumawidjaja G, Ong EHW, et al. Prognostic model for stratification of radioresistant nasopharynx carcinoma to curative salvage radiotherapy. J Clin Oncol 2018. Jco2017755165.

[108] Tian YM, Tian YH, Zeng L, Liu S, Guan Y, Lu TX, et al. Prognostic model for survival of local recurrent nasopharyngeal carcinoma with intensity-modulated radiotherapy. Br J Cancer 2014;110:297-303.

[109] Yue Q, Zhang M, Chen Y, Zheng D, Chen Y, Feng M. Establishment of prognostic factors in recurrent nasopharyngeal carcinoma patients who received salvage intensity-modulated radiotherapy: a meta-analysis. Oral Oncol 2018;81:81-8.

[110] Ng WT, Wong ECY, Cheung AKW, Chow JCH, Poon DMC, Lai JWY, et al. Patterns of care and treatment outcomes for local recurrence of NPC after definite IMRT - a study by the HKNPCSG. Head Neck 2019. [in press].

[111] National Comprehensive Cancer Network. Recent updates to NCCN clinical practice guidelines in oncology (NCCN Guidelines $\left.{ }^{\circledR}\right) ; 2019$.

[112] Tsang RK, Holsinger FC. Transoral endoscopic nasopharyngectomy with a flexible next-generation robotic surgical system. Laryngoscope 2016;126:2257-62.

[113] Stoker SD, Indrasari SR, Herdini C, Hariwiyanto B, Karakullukcu B, Dhamiyati W, et al. Photodynamic therapy as salvage therapy for patients with nasopharyngeal carcinoma experiencing local failures following definitive radiotherapy. Photodiagnosis Photodyn Ther 2015;12:519-25.

[114] Succo G, Rosso S, Fadda GL, Fantini M, Crosetti E. Salvage photodynamic therapy for recurrent nasopharyngeal carcinoma. Photodiagnosis Photodyn Ther 2014;11:63-70.

[115] Nyst HJ, Wildeman MA, Indrasari SR, Karakullukcu B, van Veen RL, Adham M, et al. Temoporfin mediated photodynamic therapy in patients with local persistent and recurrent nasopharyngeal carcinoma after curative radiotherapy: a feasibility study. Photodiagnosis Photodyn Ther 2012;9:274-81.

[116] Yeo ELL, Li YQ, Soo KC, Wee JTS, Chua MLK. Combinatorial strategies of radiotherapy and immunotherapy in nasopharyngeal carcinoma. Chin Clin Oncol 2018;7:15.

[117] Suarez C, Fernandez-Alvarez V, Hamoir M, Mendenhall WM, Strojan P, Quer M, et al. Carotid blowout syndrome: modern trends in management. Cancer Manage Res 2018;10:5617-28.

[118] Epstein JB, Song PY, Ho AS, Larian B, Asher A, Bensadoun RJ. Photobiomodulation therapy: management of mucosal necrosis of the oropharynx in previously treated head and neck cancer patients. Support Care Cancer 2017;25:1031-4.

[119] Teguh DN, Levendag PC, Noever I, Voet P, van der Est H, van Rooij P, et al. Early hyperbaric oxygen therapy for reducing radiotherapy side effects: early results of a randomized trial in oropharyngeal and nasopharyngeal cancer. Int J Radiat Oncol Biol Phys 2009;75:711-6. 